Jurnal Teknologi Pertanian Vol. 19 No. 2 [Agustus 2018] 69-74

Peramalan Persediaan Bahan Baku Pulp [Ihwah dkk]

\title{
PERAMALAN PERSEDIAAN BAHAN BAKU PULP DI PT. INDAH KIAT PULP \& PAPER TBK TANGERANG
}

\section{Forecasting Inventory of Raw Materials in PT. Indah Kiat Pulp E Paper Tbk Tangerang}

\author{
Azimmatul Ihwah*, Maulana Akbar Yudistika \\ Jurusan Teknologi Industri Pertanian - Fakultas Teknologi Pertanian - Universitas Brawijaya \\ Jalan Veteran, Malang 65145 \\ *Penulis Korespondensi: email: azimmatul.ihwah@gmail.com
}

\begin{abstract}
ABSTRAK
PT. Indah Kiat Pulp \& Paper Tbk Tangerang merupakan salah satu produsen besar yang memproduksi kertas. Struktur organisasi perusahaan bertipe fungsional dengan total tenaga kerja kurang lebih mencapai 1300 orang. Manajemen persediaan di PT. Indah Kiat Pulp \& Paper Tbk Tangerang dikelola oleh Departemen Material Management (MM). Sistem penggunaan bahan baku berupa pulp yang diterapkan di PT. Indah Kiat Pulp \& Paper Tbk Tangerang adalah make by order. Pelaksanaan proses produksi di PT. Indah Kiat Pulp \& Paper Tbk Tangerang tidak dapat mendatangkan bahan baku secara satu persatu. Bahan baku tersebut pada umumnya akan dibeli dalam jumlah tertentu, dimana dengan jumlah yang tersedia ini akan dipergunakan untuk menunjang pelaksanaan proses produksi perusahaan yang bersangkutan dalam beberapa waktu tertentu pula. Pada keadaan semacam ini, maka bahan baku yang sudah dibeli oleh perusahaan namun belum dipergunakan untuk proses produksi, akan masuk sebagai persediaan bahan baku dalam perusahaan tersebut. Hasil peramalan persediaan bahan baku satu tahun ke depan digunakan sebagai pedoman perusahaan untuk estimasi penerimaan order berdasarkan data historis persediaan bahan baku dua tahun terakhir, yaitu Agustus 2014 - Juli 2017. Model SARIMA (Seasonal ARIMA) terbaik yaitu $(0,1,1)(0,1,1) 4$ dengan MSE 0.0000109
\end{abstract}

Kata kunci : Inventory, Paper, Pulp, Manajemen, Peramalan, SARIMA

\begin{abstract}
PT. Indah Kiat Pulp \& Paper Tbk. Tangerang is one of the major producers producing paper. The organizational structure of a functional enterprise type with a total workforce of approximately 1300 people. Inventory management at PT. Indah Kiat Pulp \& Paper Tbk. Tangerang is managed by the Department of Materials Management (MM). The system of use of raw materials in the form of pulp applied in PT. Indah Kiat Pulp \& Paper Tbk. Tangerang is Make By Order. In the implementation of production process at PT. Indah Kiat Pulp \& Paper Tbk. Tangerang can not bring raw materials one by one. The raw materials will generally be purchased in certain quantities, which with the amount available will be used to support the implementation of the production process of the company concerned in some particular time as well. With this kind of circumstances, the raw materials that have been purchased by the company but not yet used for the production process will enter as raw material inventory in the company. The result of forecasting of raw material inventory is used as a guideline for the company to estimate the receipt of orders based on historical data of the last two years, namely August 2014 - July 2017. The best SARIMA (Seasonal ARIMA) model is $(0,1,1)(0,1,1) 4$ with MSE 0.0000109
\end{abstract}

Keywords : Inventory, Paper, Pulp, Management, Forecasting, SARIMA 
Jurnal Teknologi Pertanian Vol. 19 No. 2 [Agustus 2018] 69-74

Peramalan Persediaan Bahan Baku Pulp [Ihwah dkk]

\section{PENDAHULUAN}

PT. Indah Kiat Pulp \& Paper Tbk merupakan salah satu perusahaan yang bergerak dalam bidang penyedia kertas terbesar di Indonesia. Perusahaan yang berlokasi di area seluas 550 hektar yang strategis karena dekat dengan pusat distribusi di Serang, Banten. Produk-produk buatan perusahaan ini tidak hanya memenuhi pasaran domestik saja, melainkan telah menembus pasaran internasional. Perusahaan ini telah mengekspor hingga ke negara-negara di Asia, Amerika Utara dan Selatan, Australia, Afrika, dan juga Eropa.

PT. Indah Kiat Pulp \& Paper Tbk merupakan industri besar yang bergerak di bidang produksi kertas. Produk kertas yang dihasilkan oleh PT. Indah Kiat Pulp \& Paper Tbk memiliki kualitas terbaik dengan skala internasional. Sekarang ini, total 118000 ton tiap bulan atau lebih dari 1.2 juta ton tiap tahun kertas yang diproduksi PT. Indah Kiat Pulp \& Paper Tbk. Ketika memproduksi kertas yang berkualitas tinggi dengan jumlah yang besar, PT. Indah Kiat Pulp \& Paper Tbk telah menerapkan manajemen persediaan yang baik.

Menurut Ghozali (2009), forecasting adalah seni dan ilmu memprediksi peristiwa-peristiwa yang akan terjadi dengan menggunakan data historis dan memproyeksikannya ke masa depan dengan beberapa bentuk model matematis. Pulp A merupakan bahan baku utama dalam tahapan produksi kertas di PT. Indah Kiat Pulp \& Paper Tbk Tangerang. Menurut data historis yang telah dilampirkan, dapat diketahui bahwa laju ketersediaan kuantitas bahan baku pulp A sebagai bahan baku produk unggulan cenderung lebih rendah dibanding dua bahan baku lainnya yaitu pulp B dan pulp C. Metode peramalan persediaan bahan baku akan sangat berguna sekali sebagai informasi bagi perusahaan dalam melakukan perencanaan kapasitas produksi (Korpela dan Tuominen, 1996; Nilsen, 2013; Moser, 2017; Singh dan Verma, 2018).

\section{BAHAN DAN METODE}

Data persediaan bahan baku yang digunakan dalam penelitian ini adalah data sekunder berupa data historis perusahaan dalam interval waktu Agustus 2014 - Juli 2017. Selain data sekunder sebagai data utama untuk melakukan peramalan, juga dilakukan observasi dan wawancara kepada Departemen Material Management mengenai manajemen persedian bahan baku yang dilakukan sebagai data dukung yang bersifat deskriptif. Metode yang digunakan dalam penelitian ini adalah metode peramalan dengan pemilihan model terbaik.

\section{HASIL DAN PEMBAHASAN}

Pulp merupakan bahan baku utama dalam proses pembuatan produk kertas pada PT. Indah Kiat Pulp \& Paper Tbk Tangerang. Terdapat tiga jenis grade pulp yang digunakan pada proses pembuatan kertas tersebut, antara lain pulp dengan grade A, pulp dengan grade $\mathrm{B}$, dan pulp dengan grade $\mathrm{C}$. Kebutuhan bahan baku tiap grade pulp tiap tahunnya sangat variatif dan bersifat fluktuatif. Pasokan kebutuhan pada tiap grade pulp, PT. Indah Kiat Pulp \& Paper Tbk Tangerang mengadakan kerjasama dengan beberapa vendor atau supplier penyedia bahan baku pulp baik yang ada di dalam negeri atau impor. Pemesanan bahan baku pulp dilakukan berdasarkan kebutuhan produksi pada periode tersebut. Dengan kata lain, perusahaan hanya memesan bahan baku kepada vendor atau supplier ketika terdapat sejumlah order masuk yang diterima dari customer.

\section{Manajemen Persediaan Bahan Baku}

Penerapan manajemen persediaan bahan baku pulp di PT. Indah Kiat Pulp \& Paper Tbk Tangerang dilakukan berdasarkan 4 unsur yang terdiri dari Planning, Do, Control, Actuacting. Keempat unsur ini disingkat dengan PDCA. Planning adalah melakukan perencanaan untuk pelaksanaan dari solusi yang sudah dipilih. Do adalah pelaksanaan dari perancangan sebelum dilakukan di lapangan. Control adalah pengawasan yang dilakukan terhadap proyek yang telah direncanakan. Jika terjadi kesalahan perlu dilakukan perbaikan sebelum dilakukan di lapangan. Actuating adalah pelaksanaan di lapangan. Hal ini dilakukan bila proyek telah siap untuk direaliasasikan. 


\section{Aspek Planning}

Kegiatan ini melakukan break down semua kebutuhan dan kegiatan yang harus dilakukan. Mulai dari jumlah supply bahan baku, perubahan jumlah penggunaan bahan baku, lama proses produksi, efektifitas proses, dan lainnya. Planning dilakukan oleh masing-masing departemen. Departemen yang terlibat dalam aspek planning pengadaan bahan baku adalah Departemen Bussiness Unit Section, PPIC, dan Departemen Material Management. Perintah pengadaan bahan baku dikordinasikan oleh Departemen Bussiness Unit Section, kemudian perintah tersebut akan disesuaikan dengan jadwal dan rencana produksi yang disusun oleh Departemen PPIC sehingga diketahui jumlah bahan baku yang dibutuhkan. Setelah itu, maka proses pemesanan bahan baku dapat dilakukan oleh Departemen Material Management.

\section{Aspek Do}

Aspek Do adalah melakukan kegiatan yang telah direncanakan pada aspek sebelumnya. Namun tahap ini masih dalam percobaan. Hal ini disebabkan untuk mengurangi biaya rugi jika terjadi kesalahan. Selain itu, PT. Indah Kiat Pulp \& Paper Tbk Tangerang merupakan perusahaan besar, sehingga perubahan sekecil apapun akan tetap berpengaruh besar. Aspek Do tidak dilakukan hanya pada proses persediaan bahan baku saja, tetapi mulai supply sampai pengemasan.

\section{Aspek Control}

Aspek Control ini adalah kegiatan mengontrol hasil dari percobaan yang dilakukan pada Aspek Do. Pengontrolan terhadap persediaan bahan baku dilakukan oleh Departemen Quality Assurance. Jika pada saat pengontrolan didapati ketidaksesuaian, maka Departemen Quality Assurance akan melaporkan hal tersebut pada Departemen Material Managament. Ketidaksesuaian yang ditemui dapat berupa bahan baku pulp yang pecah belah dikarenakan kondisi pada saat pengiriman yang tidak dapat dikendalikan. Setelah itu, Departemen Material Managament akan menerbitkan memo kepada supplier mengenai bahan baku yang mengalami ketidaksesuaian tersebut. Jika terjadi ketidaksesuaian kembali maka dilakukan evaluasi sampai didapatkan hasil yang sesuai.

\section{Aspek Actuating}

Actuating merupakan aspek penerapan dari solusi yang telah dikontrol. Penerapan aspek ini adalah pada proses pemesanan dan pendatangan bahan baku dari supplier. Bagian ini melibatkan peran Departemen Material Management dalam mengkoordinasi dan memfasilitasi supplier mulai dari tahap pemesanan, pembelian, hingga tahap loading bahan baku di gudang.

Data historis pengadaan bahan baku dari vendor atau supplier dimulai dari bulan Agustus 2014 hingga bulan Juli 2017 yang masing-masing memiliki kuantitas sejumlah 1250000 dan 400000 dalam satuan kilogram. Hal tersebut disebabkan karena sesuai dengan bulan produksi dan supply-nya. Metode peramalan dilakukan mulai dari uji stasioneritas yang berdasarkan ragam dan rata-rata, pengujian model terbaik, serta proses peramalan yang dilakukan setelah menemukan model terbaik.

\section{Uji Stationeritas Data}

Langkah pertama dalam uji stasioneritas data adalah untuk mengetahui kondisi data yang sudah stasioner terhadap ragam dengan metode box-cox. Transformasi boxcox merupakan salah satu cara pengecekan metode berdasarkan standar deviasi terkecil. Hasil transformasi pertama diperoleh nilai $\lambda$ $=0$, maka harus dilakukan transformasi lagi karena nilai $\lambda$ belum sama dengan 1 . Setelah dilakukan transformasi kedua diperoleh nilai $\lambda=-0.5$, maka perlu transformasi lagi. Hasil transformasi ketiga diperoleh nilai $\lambda=1$, sehingga dikatakan bahwa data persediaan bahan baku telah stasioner terhadap ragam.

Langkah kedua dalam uji stasioneritas data adalah untuk mengetahui data yang sudah stasioner terhadap rata-rata berdasarkan data transformasi yang diperoleh dengan menggunakan plot ACF dan PACF seperti yang ditunjukkan pada Gambar 1 dan Gambar 2. Pada hasil plot ACF tersebut dapat disimpulkan bahwa digunakan $\mathrm{d}=1$ dalam model. Selanjutnya, dilakukan pemeriksaan sifat musiman dari data persediaan bahan baku menggunakan plot PACF.

Pada Gambar 2 memperlihatkan bahwa setiap 4 lag, data akan keluar dari interval konfidensi, sehingga dapat diduga bahwa terdapat model musiman dalam data. Model SARIMA memiliki notasi ( $p$, d, q) (P, D, Q)s. Berdasarkan pembahasan sebelumnya, didapatkan tiga buah model 
Jurnal Teknologi Pertanian Vol. 19 No. 2 [Agustus 2018] 69-74

Peramalan Persediaan Bahan Baku Pulp [Ihwah dkk]

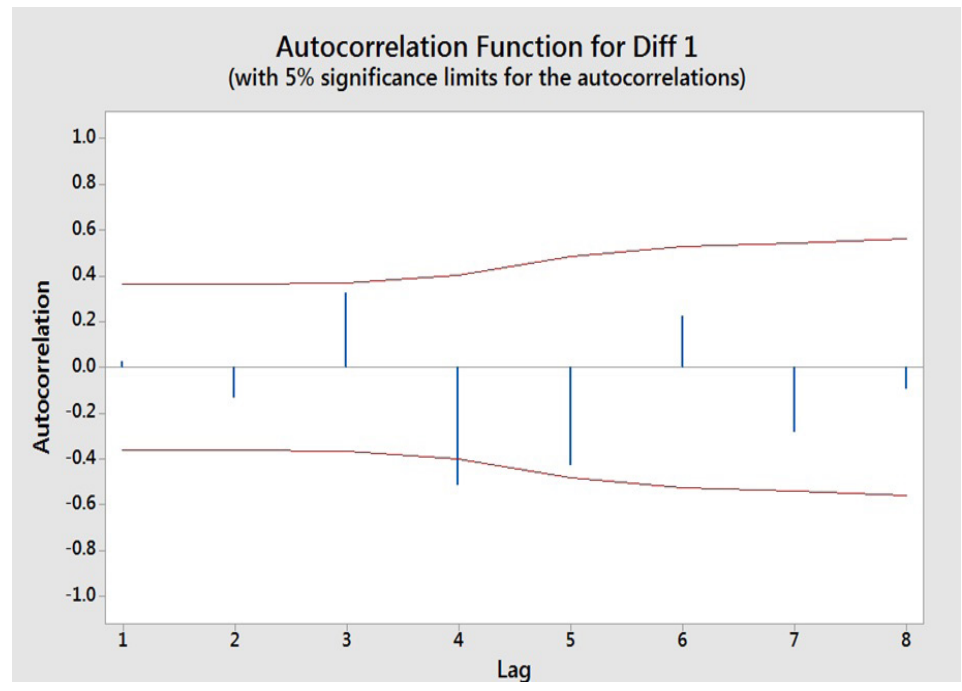

Gambar 1. Plot ACF setelah dilakukan differensiasi sebanyak 1 kali $(\mathrm{d}=1)$

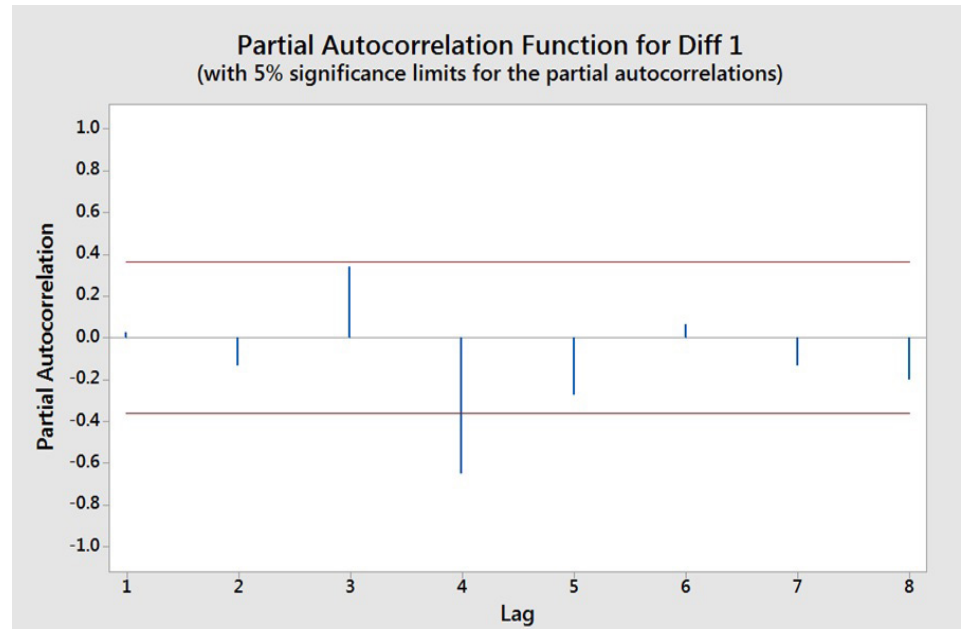

Gambar 2. Plot PACF data persediaan bahan baku dari hasil transformasi

Tabel 1. Perbandingan hasil pengujian model terbaik

\begin{tabular}{|c|c|c|}
\hline Model & P-Value & Mean Square Error (MSE) \\
\hline$(0,1,1)(1,1,1)^{4}$ & $\begin{array}{l}\text { SAR } 3(0.573) \\
\text { MA } 1(0.000) \\
\text { SMA } 3(0.000) \\
\text { Constant }(0.258)\end{array}$ & 0.0000109 \\
\hline$(1,1,0)(1,1,1)^{4}$ & $\begin{array}{l}\text { AR 1 }(0.345) \\
\text { SAR 3 }(0.985) \\
\text { SMA } 3(0.000) \\
\text { Constant }(0.837)\end{array}$ & 0.0000209 \\
\hline$(1,1,1)(1,1,1)^{4}$ & $\begin{array}{l}\text { AR } 1(0.554) \\
\text { SAR } 3(0.489) \\
\text { MA } 1(0.000) \\
\text { SMA 3 }(0.000) \\
\text { Constant }(0.609)\end{array}$ & 0.0000115 \\
\hline
\end{tabular}


yaitu $(0,1,1)(1,1,1) 4,(1,1,0) \quad(1,1,1) 4$, dan $(1,1,1)(1,1,1) 4$.

\section{Peramalan Persediaan Bahan Baku Pulp}

Berdasarkan data perbandingan hasil pengujian model tersebut, maka dapat diketahui model yang dipilih adalah $(0,1,1)$ $(1,1,1) 4$ karena memiliki nilai Mean Square yang paling rendah yaitu 0.0000109 . Namun, dikarenakan nilai SAR 3 tidak signifikan atau $p$-value $>0.05$, maka terjadi penyesuaian pada variabel autoregressive bentuk seasonal yang sebelumnya bernilai 1 diubah menjadi 0 . Adapun bentuk akhir model yang diperoleh dan sudah layak digunakan untuk forecasting adalah $(0,1,1)(0,1,1) 4$.

Peramalan menggunakan metode SARIMA dengan model $(0,1,1)(0,1,1) 4$ menghasilkan data yang bersifat fluktuatif. Peramalan kuantitas bahan baku pulp A tiap bulannya terhitung sejak bulan Agustus tahun 2017 hingga bulan Juli tahun 2018 mengalami kenaikan dan penurunan yang signifikan. Tahun 2017, mulai bulan Agustus hingga Desember rata-rata pemesanan bahan baku sebesar 1833252.89 kg. Penggunaan pulp bulan September lebih tinggi dari jumlah normal penggunaan yaitu sebesar $2364026.9 \mathrm{~kg}$. Hal ini disebabkan pada bulan September tidak ada shutdown mesin untuk keperluan maintenance, sehingga PT. Indah Kiat Pulp \& Paper Tbk Tangerang dapat memaksimalkan proses produksi yang tinggi.

Tabel 2. Hasil peramalan persediaan bahan baku pulp bulan Agustus 2017 - Juli 2018

\begin{tabular}{lcc}
\hline Bulan & Tahun & Ramalan $\mathbf{( k g )}$ \\
\hline Agustus & 2017 & 1486641.60 \\
September & 2017 & 2364026.9 \\
Oktober & 2017 & 1131238.81 \\
November & 2017 & 932859.62 \\
Desember & 2017 & 1418244.65 \\
Januari & 2018 & 697879.55 \\
Februari & 2018 & 573117 \\
Maret & 2018 & 834450.04 \\
April & 2018 & 423458.45 \\
Mei & 2018 & 347101.47 \\
Juni & 2018 & 485037.68 \\
Juli & 2018 & 254391.73 \\
\hline Jumlah & & $\mathbf{1 0 9 4 8 4 4 7 . 5}$ \\
\hline
\end{tabular}

Adapun prinsip proses produksi perusahaan bersifat make by order. Persediaan bahan baku di bulan Agustus, Oktober, November, dan Desember berkurang dari jumlah normal penggunaan disebabkan karena adanya kondisi evaluasi kinerja karyawan sehingga terjadi penyusutan angka produksi dan dipengaruhi pula habisnya kontrak kerjasama dengan beberapa supplier pemasok bahan baku di akhir tahun.

Tahun 2018, mulai bulan Januari hingga Juli rata-rata pemesanan bahan baku sebesar $516490.84 \mathrm{~kg}$. Penggunaan pulp bulan Januari, Februari, dan Maret lebih tinggi dari jumlah normal penggunaan, ketiganya sebesar 697879.55, 573117, dan $834450.04 \mathrm{~kg}$. Hal ini disebabkan adanya permintaan ekspor produk kertas jenis jumbo roll dari distributor kepada PT. Indah Kiat Pulp \& Paper Tbk Tangerang yang tinggi pada periode awal tahun. Persediaan bahan baku di bulan April, Mei, Juni, dan Juli berkurang dari jumlah normal penggunaan disebabkan karena adanya shutdown mesin pada bulan April dan pada bulan Mei hingga Juli supplier mengalami kesulitan pengadaan bahan baku karena mulai memasuki musim kemarau. Perkembangan industri pulp dan kertas di Indonesia terus meningkat dari tahun ke tahun, namun belum dapat memenuhi semua kebutuhan dalam negeri dan permintaan ekspor yang terus mengalami peningkatan (Pirard dan Irland, 2007; Raitzer, 2010; Sugesty, 2015; Tsujino et al., 2016; Wang et al., 2016). Berdasarkan data peramalan yang diperoleh sebelumnya dapat diketahui bahwa persediaan bahan baku pulp A bersifat musiman. Metode lain yang dapat digunakan pada peramalan adalah metode Jaringan Syaraf Tiruan, seperti yang dilakukan oleh Febrina et al. (2013) untuk meramalkan jumlah permintaan produksi pada perusahaan v-belt dan conveyor-belt. Metode ini merupakan alternatif baru untuk melakukan peramalan yang dapat dilakukan menggunakan beberapa faktor terkait data yang akan diramalkan.

Beberapa penelitian juga banyak dilakukan untuk pembuatan pulp dari bahan alami seperti dari batang pisang seperti yang dilakukan pada penelitian Bahri (2015) maupun Indrawan et al. (2015) dengan menggunakan bahan serat alternatif untuk membuat kertas bungkus. Hal ini dilakukan untuk mengatasi semakin menurunnya ketersediaan bahan baku pulp. 
Jurnal Teknologi Pertanian Vol. 19 No. 2 [Agustus 2018] 69-74

Peramalan Persediaan Bahan Baku Pulp [Ihwah dkk]

\section{SIMPULAN}

Hasil peramalan pada persediaan bahan baku di PT Indah Kiat Pulp \& Paper Tbk. Tangerang dapat digunakan perusahaan untuk membuat manajemen yang baik dalam pengadaan bahan baku. Manajemen pengadaan yang baik diharapkan mampu mengurangi kerugian perusahaan akibat gap besar antara persediaan bahan baku dengan target produksi. Selain metode SARIMA, metode peramalan lainnya dapat digunakan sebagai studi komparasi untuk meningkatkan ketepatan hasil peramalan.

\section{DAFTAR PUSTAKA}

Bahri, S. 2015. Pembuatan pulp dari batang pisang. Jurnal Teknologi Kimia Unimal. 4(2):36-50

Febrina, M, Arina, F, Ekawati, R. 2013. Peramalan jumlah permintaan produksi menggunakan metode jaringan syaraf tiruan (JST) backpropagation. Jurnal Teknik Industri. 1(2):174-179

Ghozali, I. 2009. Analisis Multivariate Lanjutan dengan Program SPSS. Universitas Diponegoro. Semarang

Indrawan, D, A, Efiyanti, L, Tampubolon, R, M, Roliadi, H. 2015. Pembuatan pulp untuk kertas bungkus dari bahan serat alternatif. Jurnal Penelitian Hasil Hutan. 33(4):283-302
Korpela, J, Tuominen, M. 1996. Inventory forecasting with a multiple criteria decision tool. International Journal of Production Economics. 45(1-3):159-168

Nilsen, J. 2013. Delayed production and raw materials inventory under uncertainty. International Journal of Production Economics. 146(1):337-345

Moser, $\mathrm{P}$, Isaksson, $\mathrm{O}, \mathrm{H}, \mathrm{D}$, Seifert, R, W. 2017. Inventory dynamics in process industries: an empirical investigation. International Journal of Production Economics. 191:253-366

Pirard, R, Irland, L, C. 2007. Missing links between timber scarcity and industrial overcapacity: lessons from the indonesian pulp and paper expansion. Forest Policy and Economics. 9(8):1056-1070

Raitzer, D, A. 2010. Assessing the impact of policy-oriented research: the case of CIFOR's influence on the indonesian pulp and paper sector. World Development. 38(10):1506-1518

Singh, D, Verma, A. 2018. Inventory management in supply chain. Materialstoday Proceedings. 5(2):3867-3872

Sugesty, A. 2015. Statistika Modern. Elex Media Komputindo. Jakarta

Tsujino, R, Yumoto, T, Kitamura, S, Djamaluddin, I, Darnaedi, D. 2016. History of forest loss and degradation in Indonesia. Land Use Policy. 57:335-347

Wang, Y, Yang, X, Sun, M, Ma, L, Li, X, Shi, L. 2016. Estimating carbon emissions from the pulp and paper industry: A case study. Applied Energy. 184:779-789 